\title{
PERLINDUNGAN HUKUM TENAGA KERJA INDONESIA (TKI) YANG MENJADI KORBAN KEJAHATAN DI MALAYSIA
}

\author{
Ari Heriyanto \\ Ariheriyanto12@gmail.com \\ DOI : https://doi.org/10.29313/sh.v17i1.5364
}

\begin{abstract}
ABSTRAK
Masalah pengiriman TKI ke luar negeri terutama ke Malaysia terus menimbulkan persoalan dari sisi kemanan TKI selama bekerja. TKI yang bekerja rentan menjadi korban kejahatan namun masih sangat minim memperoleh akses perlindungan hukum dari pemerintah Malaysia maupun Indonesia. Metode peneltian dalam penulisan ini menggunakan pendekatan yuridis normatif dan menggunakan data sekunder dengan teknik analisis data kualitatif. Hasil penelitian menunjukan bahwa. Kajian viktimologi terhadap tenaga kerja Indonesia khususnya wanita yang menjadi korban kejahatan disebabkan, faktor kebijakan pemerintah Malayasia di bidang keimigrasian dan ketenagakerjaan khsusunya yang bekerja di sektor informal seperti pembantu rumah tangga, faktor rendahnya pengetahuan akibat pendidikan yang rendah, skill yang tidak memenuhi standar dan adanya pihak-pihak yang ingin mengambil keuntungan dari kegiatan pengiriman TKI ke luar negeri. Bentuk perlindungan hukum yang dapat diberikan dapat berupa ganti rugi, restitusi dan kompensasi. Dalam implementasinya perlindungan terhadap tenaga kerja di luar negeri khsusunya di Malaysia masih belum efektif karena masih banyak praktek-praktek eksploitasi yang melanggar hak-hak tenaga kerja dan tidak mendapat perhatian dari pemerintah.
\end{abstract}

Kata Kunci : Perlindungan Hukum, Tenaga Kerja Indonesia.

\section{ABSTRACT}

The problem of sending migrant workers abroad, especially to Malaysia continues to cause problems in terms of the security of migrant workers while working. Migrant workers who work are vulnerable to becoming victims of crime but still have minimal access to legal protection from the Malaysian and Indonesian governments. The research method in this paper uses a normative juridical approach and uses secondary data with qualitative data analysis techniques. The results showed that. Vimtimology studies of Indonesian workers, especially women who are victims of crime, Malayasia government policy factors in the field of immigration and employment specifically those working in the informal sector such as domestic servants, factors of low knowledge due to low education, skills that do not meet standards and the existence of parties parties who want to take advantage of the activities of sending migrant workers abroad. The form of legal protection that can be provided can be in the form of compensation, restitution and compensation. In its implementation of protection for overseas workers, especially in Malaysia is still not effective because there are still many exploitation practices that violate labor rights and do not receive attention from the government.

Keywords: Legal Protection, Indonesian Workers. 


\section{PENDAHULUAN}

\section{A. Latar Belakang Masalah}

Program penempatan Tenaga Kerja Indonesia (TKI) ke luar negeri merupakan salah satu upaya penanggulan pengangguran. Peranan pemerintah dalam program ini dititikberatkan pada aspek pembinaan, serta perlindungan dan memberikan berbagai kemudahan kepada pihak yang terkait, khususnya TKI dan perusahaan jasa penempatan yang bersangkutan (PJTKI). Selain bermanfaat mengurangi pengangguran, program penempatan TKI juga memberikan manfaat lain yaitu meningkatkan kesejahteraan keluarganya melalui gaji yang diterima atau remitansi. Selain itu juga meningkatkan keterampilan TKI karena mempunyai Pengalaman kerja di luar negeri. ${ }^{1}$

Bagi negara manfaat yang diterima adalah berupa peningkatan penerimaan devisa karena para TKI yang bekerja tentu memperoleh imbalan dalam bentuk asing. Dengan disahkannya Undang-undang No. 39 tahun 2004 tentang Perlindungan dan penempatan Tenaga Kerja Indonesia di luar negeri, ini semakin jelas dan nyata kewenangan pemerintah pusat dan pemerintah daerah dalam mengatur penempatan TKI, salah satu pasalnya menyebutkan pemerintah pusat berwenang dalam mengatur, membina, melaksanakan, mengawasi penempatan,serta melindungi TKI diluar negeri. Penempatan TKI mempunyai efek negatif yaitu hak-hak mereka yang bekerja di luar negeri sering diabaikan oleh para pengusaha atau majikannya seperti di Malaysia, terbukti dengan adanya berbagai kasus-kasus yang menimpa TKI di Malaysia baik sebelum, selama bekerja maupun pada saat pulang ke daerah asal. Oleh karena itu, negara perlu melakukan penanganan secara terpadu terhadap kasuskasus yang menimpa TKI di luar negeri khususnya di Malaysia. ${ }^{2}$

\footnotetext{
${ }^{1}$ Wahyudin Ukun, Menelusuri Keberadaan TKI Ilegal di Semenanjung Malaysia, Telaah Masalahmasalah Keimigrasian, PT Adi Kencana, Jakarta, 2003, hlm 2.

${ }^{2}$ Adrian Sutedi,, Hukum perburuhan,Sinar Grafika, Jakarta, 2009, hlm 236.
} 
Faktor yang menentukan sehingga Malaysia menjadi pilihan para tenaga kerja Indonesia khususnya tenaga kerja wanita adalah hubungan transportasi relatif murah dan cepat. Beberapa pelabuhan di Indonesia merupakan pintu gerbang keluar masuk pekerja Indonesia untuk mencapai tujuan Malaysia, seperti Batam, Tanjung Pinang. Disamping itu masyarakat kedua negara merupakan suku melayu dengan bahasa yang mirip dan sejak dulu memiliki hubungan sosial budaya yang erat sehingga memudahkan dalam berinteraksi. Beberapa TKI menyatakan mereka ingin mencari suasana baru dan pengalaman baru dan menjadikan Malaysia sebagai batu loncatan untuk meraih kualifikasi yang dapat menjadikan mereka menjadi calon yang lebih baik untuk pekerjaan yang lebih menguntungkan di Timur Tengah, Singapura dan Hongkong.

Pengiriman TKI keluar negeri diikuti dengan Berbagai masalah, tenaga kerja Indonesia yang mengadu nasib di luar negeri khususnya di Malaysia yang sering terjadi karena tidak memenuhi sumber daya atau skill yang memenuhi, kerap mendapatkan pelecehan secara fisik dan psikologis termasuk pelechan seksual dan larangan untuk melakukan peribadatan agama mereka. Para tenega kerja wnita Indonesia (TKWI) menghadapi pelecehan yang sangat beragam atas hak-hak pekerja di tempat bekerja, seperti pembayaran upah yang tidak seutuhnya dan rutin, ditipu mengenai jenis dan kondisi pekerjaan, di kurung di tempat kerja, tidak menerima gaji sama sekali, bahkan sering mendapat perlakuan yang tidak manusiawi, perempuan tersebut terjebak dalam situasi perdagangan tenaga kerja dan kerja paksa. ${ }^{3}$

Fakta kasus pelecehan seksual terhadap TKWI Indonesia di Malaysia cukup banyak salah satunya adalah kasus perkosaan terhadap TKI Indonesia di Serawak telah berkali-kali terjadi. Kantor penghubung KJRI kuching bersama korban selalu mengadu pada kepolisian setempat tetapi hasilnya nihil. Fakta yang paling menyakitkan menimpa Nurjana TKI asal sintang Kalimantan Barat

\footnotetext{
${ }^{3}$ Sri Warjiati, Hukum Ketenagakerjaan dan Keselamatan Kerja dan Perlindungan Upah Pekerja
} Wanita, Tarsito Bandung, 1998, hlm 23. 
yang diperkosa dua anggota polisi Serawak bernama Ahmad bin Engge dan Sulaiman Chundi di dekat kawasan Markas Kepolisian Sektor Sri Begawan.

Masalah-masalah di atas merupakan suatu hal yang sangat penting dan mendesak untuk dicarikan penyelesaiannya karena pada posisi tersebut tenaga kerja Indonesia merupakan salah satu korban kejahatan ${ }^{4}$ yang dilakukan oleh para majikan dan pihak lain di luar negeri khususnya di Malaysia. Sehingga pemhaman terhadap korban kejahatan yang harus benar-benar disikapi oleh pemerintah Indonesia sendiri. Para TKI menjadi korban kejahatan karena posisi yang sangat lemah dimana pihak yang kuat ingin selalu menguasai pihak yang lemah, oleh karena itu perlu campur tangan pemerintah untuk menciptakan keadilan dalam hubungan ketenagakerjaan.

\section{B. Identifikasi Masalah}

1. Bagaimana kajian viktimologi tentang tenaga kerja Indonesia yang menjadi korban kejahatan di Malaysia ?

2. Perlindungan hukum apakah yang dapat diberikan terhadap tenaga kerja Indonesia oleh pemerintahan Indonesia dilihat dari peraturan perundang-undangan tentang ketenagakerjaan?

\section{Metode Penelitian}

Metode yang digunakan dalam penulisan adalah metode pendekatan yuridis normatif karena mengkaji peraturan perundang-undangan di bidang ketenagakerjaan dan perlindungan korban. Jenis data menggunakan data sekunder yang dianalisis secara kualitatif karena tidak menggunakan rumusrumus tertentu untuk memecahkan masalah.

\footnotetext{
${ }^{4}$ Theo Van Boven, Mereka Yang Menjadi Korban, Elsam, Jakarta, 2002 hlm 100
} 


\section{PEMBAHASAN}

\section{A. Kajian Viktimologi Tentang Tenaga Kerja Indonesia (TKI) di Malaysia Sebagai Korban Kejahatan}

Korban menurut Andrew Karmen dibagi menjadi dua yaitu korban langsung (primer) ialah korban yang mengalami tindakan jahat dan akibatakibat pertama kali (langsung) dan korban tidak langsung (secondary victims) seperti halnya anggota keluarga dari korban pertama yang juga secara emosional atau keuangan namun tidak terlibat atau merasakan rugi secara langsung. ${ }^{5}$

Kasus tenaga kerja Indonesia yang berprofesi sebagai pembantu rumah tangga yang pada umumnya adalah perempuan bisa dikatakan bahwa hal itu adalah kekerasan terhadap perempuan berbasis gender. Hal ini sesuai dengan pernyataan Ramony Sihite yang berbunyi "khusus mengenai korban kejahatan atau tindak kekerasan yang khas dan ditujukan pada perempuan karena mereka perempuan biasa disebut kekerasan berbasis gender (Gender Based Violence). ${ }^{6}$

Berbagai praktek viktimisasi terhadap TKI yang bekerja sebagai pembantu rumah tangga yang melanggengkan hubungan yang tidak simetris antara majikan dan TKI. Praktek viktimisasi ini juga akibat kebijakan pemerintah Malaysia yang tidak memihak TKI. Viktimisasi yang terjadi pada TKI dapat terlihat dati eksploitasi yang dilakukan oleh majikan dengan jam kerja yang panjang tanpa diiringi dengan upah lembur ataupun tunjangan lain hal ini merupakan sebuah bentuk eksploitasi terhadap seorang pekerja.. dilihat dari bentuknya eksploitasi terbagi menjadi

${ }^{5}$ Ibid, hlm 245.

${ }^{6}$ Ramony Sihite, Kekerasan Negara Terhadap Perempuan, Jurnal Kriminologi Indonesia, Vol 3 No 1 Juni 2003, hlm 29. 
eksploitasi tenaga kerja dan eksploitasi tenaga kerja. Eksploitasi tenaa kerja dapat berbentuk bekerja dengan paksa, perbudakan, atau praktek-praktek yang menyerupainya. ${ }^{7}$

Para TKI terviktimisasi dengan berbagai kebijakan pemerintah Malaysia baik itu kebijakan imigrasi dan kebijakan ketenagakerjaan. Pada kebijakan imigrasi Malaysia mereka yang didapati bersalah secara hukum dapat dicambuk atau dipenjara selama 5 tahun, didenda dengan sangat berat dan ditahan tanpa batas waktu sampai mereka dipulangkan. ${ }^{8}$ Hal ini mengakibatkan rentannya buruh migran Indonesia menjadi korban pelanggaran HAM.

Kebijakan imigrasi demikian mengakibatkan banyaknya TKI yang terpaksa bertahan mendapatkan perlakuan majikan mereka yang mengeksploitasi tenaga mereka dan melakukan berbagai kekerasan. ${ }^{9}$ mereka terpaksa pasrah selain gaji mereka ditahan juga takut dideportasi, mendapatkan hukuman dicambuk juga karena ketiadaan kesempatan. Hukum ketenagakerjaan Malaysia pun membuat mereka terviktimisasi dimana undang-undang tersebut tidak mengakomodasi beberapa kunci perlindungan bagi para TKI. Sumber prinsip dari hukum ketenagakerjaan Malaysia adalah undang-undang tenaga kerja Malaysia memasukan "domestic servants" dalam kategori yang dicakup undang-undang melindungi mereka dari pembayaran gaji yang tidak teratur atau terlambat, tetapi secara rinci meniadakan ketentuan hari istirahat (libur) jam kerja, libur hari besar, cuti tahunan, cuti sakit, dan perlindungan maternas.

\footnotetext{
${ }^{7}$ Muhammad Satar, Pengembangan SDM Indonesia, Unggul Menghadapi Masyarakat Kompetitif Era Globalisasi, Jurnal Sosial dan Pembangunan, Vol XVIII No 4 Desember, LPPM Unisba, 2004, Hlm 433.

${ }^{8} \mathrm{http} / /$ www.hrw.org./Indonesia.does/2007/11/19/Malaysia9707.html.23:00.

${ }^{9}$ Asri Wijayanti, Hukum Ketenagakerjaan Pasca Reformasi, Sinar Grafika, Jakarta, 2013, Hlm 98.
} 
Pekerja rumah tangga juga ditiadakan dari tunjangan-tunjangan pemecatan lay-off dan pengunduran diri. Undang-undang kompensasi Malaysia tahun 1952 yang menyediakan mekanisme bagi para pekerja untuk menerima kompensasi karena kecelakaan kerja dan sakit akibat bekerja juga ditiadakan bagi para TKI yang berprofesi sebagai pembantu rumah tangga. Majikan di Malaysia secara rutin memerlukan pekerja rumah tangga Indonesia untuk bekerja 14 hingga 20 jam sehari, 7 hari dalam seminggu dengan tanpa istirahat. ${ }^{10}$ Hal ini melanggar hak asasi manusia yang dituangkan dalam instrumen internasional artikel 24 Deklarasi Univeral Tentang Hak Asasi Manusia yang menyebutkan:

"Setiap orang mempunyai hak untuk istirahat dan bersenangsenang termasuk pembatasan jam kerja dan hari libur berkala dengan upah"

Faktor lain yang mengakibatkan TKI Indonesia menajdi korban kejahatan di Malaysia adalah faktor rendahnya pengetahuan karena kurangnya pendidikan sehingga mereka harus mencari pekerjaan ke luar negeri tanpa pengetahuan yang cukup maka hal ini akan menjadi faktor viktimogen bagi diri mereka sendiri. Secara garis besar faktor penyebab TKI menjadi korban kejahatan di Malaysia adalah:

1. Kurangnya pengetahuan akibat rendahnya pendidikan, mayoritas tenaga kerja di Indonesia adalah lulusan SD dan SMP.

2. Akibat perbuatan diri mereka sendiri karena tidak mempersiapkan diri secara administratif dan skill yang memadai, fakta menunjukan bahwa mayoritas dari TKI yang datang ke Indonesia bekerja di sektor informal.

3. Pihak ketiga yang tidak bertanggung jawab baik agen-agen yang tidak bertanggung jawab sampai para majikan yang tidak manusiawi.

Berdasarkan uraian di atas maka dapat dkaji bahwa pengetahuan TKI yang rendah, skill yang tidak memadai dan adanya pihak-pihak yang ingin memperoleh keuntungan dari kegiatan pengiriman tenaga kerja

${ }^{10}$ Hardijan Rusli, Hukum Ketenagakerjaan, Ghalia Indonesia, Bogor, 2011, Hlm 21. 
Indonesia ke luar negeri menjadi serangkaian penyebab yang menjadi faktor viktimogen para TKI yang bekerja di luar negeri khususnya Malaysia. Dikaji dari aspek viktimologi faktor-faktor di atas merupakan penyebab TKI menjadi korban kejahatan faktor tersebut ada yang bersumber dari diri korban (internal), akan tetapi ada juga yang berasal dari luar korban (eksternal). Untuk itu perlu adanya campur tangan dari pemerintah Indonesia untuk memberikan perlindungan terhadap para TKI yang cenderung memiliki posisi lemah. Posisi TKI yang lemah ini kemudian dimanfaatkan oleh pihak-pihak yang ingin mengambil keuntungan dari kegiatan pengitiman TKI ke beberapa negara.

\section{B. Perlindungan Hukum Terhadap Tenaga Kerja Indonesia Oleh Pemerintahan Indonesia Dilihat Dari Peraturan Perundang-undangan Tentang Ketenagakerjaan}

Beberapa ketentuan yang berkaitan dengan perlindungan bagi tenaga kerja Indonesia (TKI) diatur dalam Pasal 77, Pasal 78 ayat (1) dan Pasal 80 ayat (1) Undang-undang No 39 Tahun 2004 Tentang Penempatan dan Perlindungan Tenaga Kerja Inodnesia ke Luar Negeri. Pasal 77 Undang-undang No 39 Tahun 2004 menyatakan bahwa:

(1) Setiap calon TKI/TKI mempunyai hak untuk memperoleh perlindungan sesuai dengan peraturan perundang-undangan

(2) Perlindungan sebagaimana dimaksud pada ayat (1) dilaksanakan dari pra penempatan, masa penempatan, sampai dengan purna penempatan

Selanjutnya dalam Pasal 78 ayat (1) Undang-undang No 39 Tahun 2004 menyatakan bahwa:

"Perwakilan Republik Indonesia memberikan perlindungan terhadap TKI di luar negeri sesuai dengan peraturan perundang-undangan serta hukum dan kebiasaan internasional"

Lebih lanjut dalam Pasal 80 ayat (1) Undang-undang No 39 Tahun 2004 menyatakan bahwa Perlindungan selama masa penempatan TKI di luar negeri dilaksanakan antara lain: 
a. Pemberian bantuan hukum sesuai dengan peraturan perundang-undangan di Negara tujuan serta hukum dan kebiasaan internasional

b. Pembelaan atas pemenuhan hak-hak sesuai dengan perjanjian kerja dan/atau peraturan perundang-undangan di Negara TKI ditempatkan.

Dengan dikeluarkanya Undang-undang No 39 Tahun 2004 tentang penempatan dan perlindungan tenaga kerja Indonesia di luar negeri, pada dasarnya pemerintah Indonesia telah berupaya memberikan perlindungan hukum bagi tenaga kerja Indonesia (TKI) yang bekerja di luar negeri, begitu juga bagi para tenaga kerja Indonesia (TKI) yang bekerja di Malaysia. Hal tersebut ditegaskan pada Pasal 77 dan 78 ayat (1) Undang-undang No 39 Tahun 2004, yang menyebutkan bahwa tenaga kerja Indonesia (TKI) yang bekerja di luar negeri termasuk di Malaysia berhak mendapatkan perlindungan hukum dari pemerintah Indonesia.

Pada Pasal 77 ayat (2) disebutksn bahwa tenaga kerja Indonesia (TKI) mendapatkan perlindungan pada pra penempatan, masa penempatan, sampai dengan purna penempatan. Perlindungan pada masa pra penempatan bagi tenaga kerja Indonesia (TKI) antara lain:

a. Para calon tenaga kerja Indonesia (TKI) diharuskan mengikuti semua syarat-syarat yang ditentukan atau sesuai dengan prosedur yang telah ditentukan untuk bekerja di luar negeri khsusunya Malaysia.

b. Para calon tenaga kerja Indonesia (TKI) diwajibkan mendapatkan pelatihan dan juga diwajibkan mengikuti program asuransi untuk dapat bekerja di luar negeri termasuk di Malaysia.

c. Perlindungan diberikan pada saat tenaga kerja Indonesia tersebut melakukan pelatihan sebelum berangkat bekerja di Malaysia.

d. Perlindungan diberikan pada saat tenaga kerja Indonesia tersebut berada di tempat penampungan sebelum ditempatkan bekerja di Malaysia.

Perlindungan yang diberikan pada masa pra penempatan tenaga kerja Indonesia (TKI) lebih bersifat preventif atau bersifat mencegah agar 
sesuatu hal yang tidak diinginkan tidak terjadi. ${ }^{11}$ Perlindungan bagi tenaga kerja Indonesia (TKI) pada masa pra penempatan diberikan karena, tidak sedikit calon tenaga kerja Indonesia (TKI) yang berada di pusat pelatihan atau di tempat penampungan yang mengalami tindakan yang tidak semestinya dari para agen tenaga kerja Indonesia (TKI) tersebut, seperti para tenaga kerja Indonesia tersebut kekurangan makan dan minum, tempat yang tidak memadai dimana ruang gerak bagi para calon tenaga kerja Indonesia (TKI) tersebut sangat terbatas dan juga tidak sedikit dari calon tenaga kerja Indonesia (TKI) yang mengalami kekerasan fisik dan juga pelecehan seksual. ${ }^{12}$

Selain pada masa pra penempatan, perlindungan bagi tenaga kerja Indonesia (TKI) juga diberikan selama tenaga kerja Indonesia (TKI) tersebut bekerja di luar negeri, begitu juga bagi tenaga kerja Indonesia yang berada di Malaysia. Seperti yang tercantum dalam Pasal 80 ayat (1) Undangundang No 39 Tahun 2004, bahwa perlindungan yang diberikan selama tenaga kerja Indonesia (TKI) tersebut bekerja adalah:

a. Pemberian bantuan hukum yang mana harus sesuai dengan ketentuan peraturan-perundang-undangan Negara tempat tenaga kerja Indonesia (TKI) tersebut bekerja yaitu aturan hukum yang berlaku di malaysia.

b. Pembelaan atas pemenuhan hak-hak yang sesuai dengan perjanjian kerja dan juga peraturan perundang-undangan dimana tenaga kerja Indonesia (TKI) tersebut bekerja.

Berkaitan dengan kejahatan yang dialami oleh tenaga kerja Indonesia (TKI) di Malaysia, maka sudah semestinya tenaga kerja Indonesia (TKI) tersebut mendapatkan perlindungan hukum, sesuai dengan ketentuan

${ }^{11}$ Abdul Hakim, Hukum Ketenagakerjaan Indonesia, PT Citra Aditya Bakti, Bandung, 2009, hlm 34.

12 www.human right.watch.2008.com diakses 17-03-13 pkl 12.30 
yang terdapat dalam Pasal 80 ayat (1) Undang-undang No 39 Tahun 2004 ini. Sementara perlindungan yang diberikan pada masa purna penempatan yakni pada saat Tenaga Kerja Indonesia (TKI) pulang ke Indonesia adalah pelayanan yang memadai, baik dari segi informasi seperti memasang sistem pemantauan pada terminal kedatangan Tenaga Kerja Indonesia (TKI) untuk menginformasikan mengenai hak-hak para Tenaga Kerja Indonesia (TKI) yang membutuhkan perawatan kesehatan sesampainya Tenaga Kerja Indonesia (TKI) yang menderita kekerasan fisik dan pelecehan seksual yang perlu segera mendapatkan perawatan. ${ }^{13}$

Perlindungan hukum tidak hanya diberikan bagi Tenaga Kerja Indonesia (TKI) yang legal (resmi) saja, tetapi perlindungan hukum juga sudah semestinya diberikan bagi Tenaga kerja Indonesia (TKI) yang ilegal, karena pada dasarnya tenaga kerja Indomesia (TKI) adalah manusia yang memiliki hak asasi untuk mendapatkan perlindungan hukum apabila mengalami suatu tindak kejahatan, begitu juga bagi para tenaga kerja Indonesia (TKI) yang berada di Malaysia, apabila mengalami suatu tindak pidana, seperti pemerkosaan, penganiayaan, pelecehaan seksual dan juga penipuan, sudah semestinya tenaga kerja Indonesia (TKI) illegal tersebut mendapatrkan perlindungan hukum.

Beberapa bentuk perlindungan terhadap korban baik yang berada dalam negeri mapun diluar negeri khususnya TKI di Malaysia, yaitu:

a. Ganti rugi

Istilah ganti kerugian digunakan oleh KUHAP dalam Pasal 99 ayat (1) dan (2) dengan penekanan pada penggantian biaya yang telah dikeluarkan oleh pihak yang dirugikan atau TKI yang menjadi korban kejahatan di Malaysia. Dilihat dari kepentingan korban, dalam konsep ganti kerugian terkandung dua manfaat yaitu pertama, untuk memenuhi kerugian

${ }^{13}$ Bandingkan dengan Boer Mauna, Perkembangan Hukum Internasional dan Upaya Penegakannya Dewasa Ini, Jurnal Syiar Madani Ilmu Hukum, Vol V No 1 Maret, Fakultas Hukum Unisba, 2003, Hlm 6 
material dan segala biaya yang telah dikeluarkan. Kedua merupakan pemuasan emosional korban. Sedangkan dilihat dari sisi kepentingan si pelaku, kewajiban mengganti kerugian di pandang sebagai suatu bentuk pidana yang dijatuhkan dan dirasakan sebagai suatu yang konkrit dan langsung berkaitan dengan kesalahan yang diperbuat pelaku. ${ }^{14}$

b. Restitusi (restitution)

Restitusi lebih diarahkan pada tanggung jawab pelaku terhadap akibat yang ditimbulkan oleh kejahatan sehingga sasaran utamannya adalah menanggulangi semua kerugian yang diderita korban. Tolok ukur yang digunakan dalam menentukan jumlah resitusi yang diberikan tidak mudah dalam merumuskannya. Hal ini tergantung pada status soial pelaku dan korban. Dalam hal korban dengan status sosial lebih rendah dari pelaku, akan mengutamakan ganti kerugian dalam bentuk materi, dan sebaliknya jika status korban lebih tinggi dari pelaku maka pemulihan harkat serta nama baik akan lebih di utamakan.

c. Kompensasi

Kompensasi merupakan bentuk santunan yang dapat dilihat dari aspek kemanusiaan dan hak-hak asasi. Adannya gagasan mewujudkan kesejahteraan sosial masyarakat dengan berlandaskan pada komitmen kontrak sosial dan solidaritas sosial menjadikan masyarakat dan Negara bertanggungjawab dan berkewajiban secara moral untuk melindungi warganya, khususnya mereka TKI yang mengalami musibah sebagai korban kejahatan di Malaysia. Kompensasi sebagai bentuk santunan yang sama sekali tidak tergantung bagaimana berjalannya proses peradilan dan putusan yang dijatuhkan, bahkan sumber dana untuk itu diperoleh dari pemerintah atau dana umum.

${ }^{14}$ Chaerudin dan Syarif Fadillah, Korban Kejahatan Dalam Persfektif Viktimologi dan Hukum Pidana Islam, Ghardika Press, Jakarta, 2004, hlm 65 
Pada prakteknya, pelaksanaan undang-undang ini tidak berjalan dengan semestinya, karena masih banyak terjadi tindak pidana penganiayaan, perkosaan, pelecehan seksual, dan juga penipuan yang dialami oleh tenaga kerja Indonesia (TKI) di Malaysia. Hal tersebut membuktikan bahwa tenga kerja Indonesia (TKI) tidak mendapat perlindungan hukum yang semestinya seperti yang tercantum dalam ketentuan Pasal 77, Pasal 78 ayat (1) dan juga Pasal 80 ayat (1) Undangundang No 39 Tahun 2004 Tentang penempatan dan perlindungan tenaga kerja Indonesia di luar negeri.

\section{PENUTUP}

\section{A. Simpulan}

1. Kajian viktimologi terhadap tenaga kerja Indonesia khususnya wanita yang menjadi korban kejahatan disebabkan oleh beberapa yaitu : pertama, faktor kebijakan pemerintah Malayasia di bidang keimigrasian dan ketenagakerjaan yang tidak mengakomodir hak-hak tenaga kerja Indonesia khsusunya yang bekerja di sektor informal seperti pembantu rumah tangga sehingga menjadikan para tenaga kerja Indonesia sebagai korban kejahatan sekaligus korban kebijakan pemerintah tempat dimana mereka bekerja. Kedua, faktor rendahnya pengetahuan akibat pendidikan yang rendah, skill yang tidak memenuhi standar dan syaratsyarat adminitratif yang tidak terpenuhi. Ketiga, adanya pihak-pihak yang ingin mengambil keuntungan dari kegiatan pengiriman TKI ke luar negeri.

2. Perlindungan hukum terhadap tenaga kerja Indonesia yang bekerja di luar negeri telah diatur dalam Pasal 77, 78 dan 80 Undang-undang No 39 Tahun 2004 Tentang Penempatan dan Perlindungan Tenaga Kerja Indonesia ke Luar Negeri. Bentuk perlindungan hukum yang dapat diberikan dapat berupa ganti rugi, restitusi dan kompensasi. Dalam implementasinya perlindungan terhadap tenaga kerja di luar negeri 
khsusunya di Malaysia masih belum efektif karena masih banyak praktek-praktek eksploitasi yang melanggar hak-hak tenaga kerja dan tidak mendapat perhatian dari pemerintah.

\section{B. Saran}

1. Bagi pemerintah yang dapat diberikan pertama, perlu melakukan kerjasama yang intens dengan beberapa negara yang menjadi tujuan pengiriman tenaga kerja Indonesia khususnya Malaysia mengenai perlindungan hak-hak TKI yang bekerja di negara tersebut khususnya mengenai hak untuk mendapatkan upah yang layak dan rutin dan hak untuk tidak disiksa. Kedua, meningkatkan kualitas SDM TKI yang akan bekerja ke luar negeri. Ketiga, melakukan penindakan terhadap pihakpihak yang melakukan pengiriman TKI secara ilegal karena akan membahayakan jiwa TKI yang bersangkutan dan berpotensi membuka peluang perdagangan manusia.

2. Pemerintah harus melakukan pengawasan terhadap kegiatan pengiriman TKI ke luar negeri dan memastikan bahwa mereka telah bekerja sesuai dengan yang telah diperjanjikan sebelumnya dan memperoleh penghasilan yang layak dan rutin. Mengingat lemahnya posisi TKI yang bekerja ke luar negeri sehingga perlu memperoleh pengawasan dari pemerintah melalui instansi yang bertanggung jawab di bidang ketenagakerjaan. 


\section{DAFTAR PUSTAKA}

\section{A. Buku}

Abdul Hakim, Hukum Ketenagakerjaan Indonesia, PT Citra Aditya Bakti, Bandung, 2009.

Adrian Sutedi, Hukum perburuhan,Sinar Grafika, Jakarta, 2009.

Andrew Karmen, Deviants, Victim or Victimizer, London, Sage Publication, 1983.

Asri Wijayanti, Hukum Ketenagakerjaan Pasca Reformasi, Sinar Grafika, Jakarta, 2013.

Chaerudin dan Syarif Fadillah, Korban Kejahatan Dalam Persfektif Viktimologi dan Hukum Pidana Islam, Ghardika Press, Jakarta, 2004.

Hardijan Rusli, Hukum Ketenagakerjaan, Ghalia Indonesia, Bogor, 2011.

Rena Yulia, Viktimologi Dalam Sistem Peradilan Pidana, Graha Ilmu, Yogyakarta, 2010.

Sri Warjiati, Hukum Ketenagakerjaan dan Keselamatan Kerja dan Perlindungan Upah Pekerja Wanita, Tarsito Bandung, 1998.

Theo Van Boven, Mereka Yang Menjadi Korban, Elsam, Jakarta, 2002.

Wahyudin Ukun, Menelusuri Keberadaan TKI Ilegal di Semenanjung Malaysia, Telaah Masalah-masalah Keimigrasian, PT Adi Kencana, Jakarta, 2003.

\section{B. Jurnal}

Bandingkan dengan Boer Mauna, Perkembangan Hukum Internasional dan Upaya Penegakannya Dewasa Ini, Jurnal Syiar Madani Ilmu Hukum, Vol V No 1 Maret, Fakultas Hukum Unisba, 2003.

Muhammad Satar, Pengembangan SDM Indonesia, Unggul Menghadapi Masyarakat Kompetitif Era Globalisasi, Jurnal Sosial dan Pembangunan, Vol XVIII No 4 Desember, LPPM Unisba, 2004.

Ramony Sihite, Kekerasan Negara Terhadap Perempuan, Jurnal Kriminologi Indonesia, Vol 3 No 1 Juni 2003. 


\section{Peraturan Perundang-undangan}

Undang-undang Dasar 1945

Undang-undang 39 Tahun 2004 Tentang Penempatan dan Perlindungan Tenaga Kerja Indonesia ke Luar Negeri.

Undang-undang 13 Tahun 2003 Tentang Ketenagakerjaan 